\title{
Teaching Business Studies to Far East Students in the UK
}

\author{
Irene C L Ng, Ph.D.
}

\begin{abstract}
This chapter offers insights into the challenges students from the Far East face on courses in the UK. In addition, it investigates students' perceptions of the value of the business education obtained in the UK, and of the applicability of that education in the students' home countries. The results show that Far Eastern students employ thinking strategies that are different from Western students; they face dissonance in studying ethics and corporate social responsibility, which they consider as a 'Western logic'; they have difficulties in understanding Western-based epistemology; and they look on a UK education more as a signaling/certification tool than as a valuable learning experience. The study concludes with suggestions on how some of the issues raised could be addressed.
\end{abstract}

\section{Introduction}

Business education in the UK has become immensely popular amongst Far East ${ }^{1}$ students. The UK Higher Education Statistics Agency reported a 6.1\% increase in overseas students for 2004/05, to a total of 318,400 , with business and Administration being the most popular subjects and accounting for $27 \%$ of total overseas students doing higher education in the UK. After the EU, China is the number one contributor of students, with Malaysia, Singapore, Japan, Hong Kong and Taiwan within the top ten list (Higher Education Statistics Agency, 2006). This phenomenon is not restricted to the UK: in Canada, out of 70,000 foreign students enrolled in Canadian Universities, almost 5 out of every 10 were from Asia, and China accounted for almost 44\% of these Asian students (University Enrolment, 2005).

This qualitative study endeavors to bring insights into two issues. First, to understand the teaching and learning difficulties faced when Far East students come to the UK for education, and secondly to understand how students perceive the value of the business education obtained and its perceived applicability in the students' home countries. The chapter reviews the differences in typical Western ${ }^{2}$ and Eastern thought processes, and how these create a learning/teaching gap. It then follows on to discuss cultural issues that surface in learning business, particularly as business as an academic subject is of Western origin and is also valued precisely because of that. Eastern and Western business styles are also discussed.

Following on from the literature review, the chapter presents its methodology and findings. Four major issues are presented that pose a learning/teaching challenge in the delivery of business education. The chapter concludes with a discussion of the findings and how instructors could manage the challenges faced in teaching a multicultural and multinational classroom.

\section{Reference Context}

The IDP forecasts growth in higher education worldwide from around 100 million places in 2000 to 260 million in 2025, of which 7 million will be international students going overseas or taking courses from overseas (Daniel, 2004). Far East students, particularly from China, are amongst the highest in numbers. The reasons are both economic and cultural. Nine years after the financial crisis of 1997, Asian economies are enjoying a comeback and many East Asians have embraced capitalism with a passion. Making money is now the order of the day and business seems to be the vehicle towards wealth and prosperity. With increased economic activity, the demand for business skills has increased and so have the salaries of graduates. This situation is even more pronounced in China, where the last two decades of economic liberalization have brought in immense investments, to the extent that there has been a critical shortage of employees trained in management (Lau and Roffey, 2002). This has resulted in high 
numbers of Chinese students studying overseas, as well as a proliferation of management education and executive training programmes being made available within China (McGugan, 1995). The drive to acquire business skills, information and strategies has also pushed the number of MBAs awarded globally to record numbers $(\mathrm{Ng}, 2006)$.

Another reason for an increased interest in education is cultural: Confucian philosophy and East Asian upbringing place tremendous value on education. Even in the United States, where $5.5 \%$ of the population was Asian in 1995, Asians accounted for $40 \%$ of the students in the University of California, a testimony that education is part of an "investment culture of Asians" (de Bono, 1996, p. 56), and that the pursuit of education is expected of young people, rather than something they could choose not to engage in. With higher student mobility, higher education institutions worldwide have to cope with increased diversity in the classroom, and educators are faced with the issue of multiculturalism.

\section{Literature Review}

Multiculturalism is the buzz-word of this age, where calls for greater acceptance and tolerance are made in every context, be it in politics, business, economics or education. As Trotman (2002) puts it, "multiculturalism tries to restore a sense of wholeness in a postmodern era that fragments human life and thought" (p. ix). Hence, multiculturalism emphasizes mutual respect and tolerance of each other's cultures.

In Asia, multicultural life began long before the word was coined. Malaysia, Singapore and indeed, the whole of South-East Asia has been a collection of multicultural societies since trade began in the third century, as travelers from various origins stayed on in their host countries and eventually made them their own (Stuart-Fox, 2003). The coordination and management of multiculturalism, borne out of necessity, has been embedded in the lifestyles, beliefs, actions and growth of such societies. A Chinese in Malaysia speaks an average of three languages, and exhibits a mix of nationalistic, ethnic, religious and acculturated characteristics in their everyday lives. However, since multiculturalism in these societies is a tacit practice, there has been little research or documentation until lately as to what has worked and what has not. Although studied by anthropologists, the anthropological account of culture is so complex that it does not sufficiently inform the study of multiculturalism for the purpose of action, policies or thought within a multicultural society (cf. Turner, 1994). Clearly, multiculturalism is not merely a study of cultures but also one that has a purpose, i.e. as Turner puts it, "a conception of culture as empowerment for collective action, self production and struggle" (p. 424).

Nowhere is this truer than in multicultural education. Research on multicultural education focuses on ethnic identities and cultural pluralism with the aim of either reducing prejudice and discrimination in the classroom to promote a shared culture (i.e. 'melting pot' perspective, cf. McNergney and Herbert, 2001), or promoting core human values ('global' perspective, cf. Ameny-Dixon, 2004). The former view has its origins in the USA, where smaller cultures are expected to give up their identities to assimilate into a shared American macroculture (Bennett, 2003). The latter view seeks to dispel the idea of having only one way of thinking and one way of life, and strives instead to promote respect and appreciation of various cultures by increasing cultural competency (Green, 1989; Gollnick and Chinn, 2002), i.e. a concept of a cultural mosaic rather than a melting pot (McNaught, 1988). Clearly the melting pot perspective may not be applicable in an institution of higher education where the diversity of cultures arises from having students from all over the world, rather than cultures within a country. Such students do not wish to give up their cultural identities as they may have no wish to stay on after their studies and indeed, most would choose to return to their home countries after acquiring their foreign degree. Even the global perspective of multicultural education does not provide sufficient answers, particularly when students come from vastly different educational systems and societies, have dissimilar values and subscribe to different philosophies, with much of it is tacitly embedded in language, lifestyles and social networks. In other words, with today's instructors faced with both a multicultural and a multinational classroom, lessons from existing scholarship in multicultural education seem inadequate to assist instructors in delivering a better education experience.

The differences in learning styles may be more pronounced in the case of Far East students, particularly those with Confucian backgrounds. Far East cultures are generally considered to have 
different approaches to philosophy, knowledge and debate, and to exhibit different habits of mind. Despite some reservations (e.g. Ortner, 2003), Nisbett's (2003) review of numerous research papers in experimental psychology demonstrates that the Western Aristotelian-based attitude is based in the need to control others and the world through the creation of mental models by categorizing objects and events to answer the questions of 'why?' and 'who is right?'. This attitude focuses on attempting to obtain underlying principles through debate, and is linked into thinking that education is good in its own right. In contrast, the Eastern, Confucian-based attitude is not concerned with control of others or the environment, but is rather concerned with self-control. Debate is discouraged as leading to discord, and there is often a willingness to concede merit in the other person's point of view. There is not really an interest in 'why?' or 'who is right?' but rather in answering more pragmatic 'how' questions. Education, in this regard is valued for the practical consequences of action. A compilation of the differences between 'Western' and 'Eastern' habits of mind arising from this attitude is presented in Table 1. Admittedly, there are differences between Asian countries, as well as gender differences which interact with culture (just as it is similarly flawed to consider Westerners as a homogenous group). Yet broad differences exist, and it is not surprising that a learning/teaching gap may exist when Far East students study in the UK.

Table 1: The differences in the Aristotelian and the Confucian habits of mind compiled from Nisbett (2003).

\begin{tabular}{|l|l|l|}
\hline $\begin{array}{l}\text { Key elements where } \\
\text { thought processes } \\
\text { may differ }\end{array}$ & $\begin{array}{l}\text { 'Western' thought } \\
\text { process }\end{array}$ & $\begin{array}{l}\text { 'Eastern' thought } \\
\text { process }\end{array}$ \\
\hline $\begin{array}{l}\text { Patterns of } \\
\text { attention and } \\
\text { perception }\end{array}$ & $\begin{array}{l}\text { Attending to objects } \\
\text { and classifications }\end{array}$ & $\begin{array}{l}\text { Attending to } \\
\text { environments and } \\
\text { relationships }\end{array}$ \\
\hline $\begin{array}{l}\text { Basic assumptions } \\
\text { about the nature of } \\
\text { the world }\end{array}$ & $\begin{array}{l}\text { World consists of } \\
\text { separate objects }\end{array}$ & $\begin{array}{l}\text { World consists of } \\
\text { seamless } \\
\text { substances }\end{array}$ \\
\hline $\begin{array}{l}\text { Controllability of } \\
\text { the environment }\end{array}$ & $\begin{array}{l}\text { Environment can be } \\
\text { changed and } \\
\text { controlled }\end{array}$ & $\begin{array}{l}\text { Environment needs } \\
\text { adjusting to }\end{array}$ \\
\hline $\begin{array}{l}\text { Tacit assumptions } \\
\text { about stability and } \\
\text { change }\end{array}$ & Assumes stability & Assumes change \\
\hline $\begin{array}{l}\text { Preferred patterns } \\
\text { of explanation of } \\
\text { events }\end{array}$ & $\begin{array}{l}\text { Focuses on the } \\
\text { specific and on } \\
\text { objects }\end{array}$ & $\begin{array}{l}\text { Focuses on the } \\
\text { broader context and } \\
\text { environment }\end{array}$ \\
\hline Use of formal logic & $\begin{array}{l}\text { Formal logic central } \\
\text { to understanding of } \\
\text { events }\end{array}$ & $\begin{array}{l}\text { Formal logic set } \\
\text { aside to attain } \\
\text { desirable } \\
\text { conclusions }\end{array}$ \\
\hline Use of dialectical & Hegelian approach & Confucian approach \\
\hline
\end{tabular}




\begin{tabular}{|l|l|l|}
\hline approaches & $\begin{array}{l}\text { with confrontation } \\
\text { between thesis and } \\
\text { antithesis leading to } \\
\text { new synthesis and } \\
\text { superior answer }\end{array}$ & $\begin{array}{l}\text { seeking the Middle } \\
\text { Way allowing for the } \\
\text { correctness of the } \\
\text { other's viewpoint }\end{array}$ \\
\hline
\end{tabular}

Cultural characteristics also influence the structure of communities. Tsang (1998), referring to an earlier work by Hwang (1987), observes that "many Chinese have lived in encapsulated communities that are hierarchically organized, with major economic and other resources controlled by a few power figures who could arbitrarily allocate resources" (p.65). Hence, cultural issues have had a tremendous influence on structural, political and economic organization in Eastern societies; in other words, the Eastern habit is not merely cultural but also structural, allowing for the culture to be expressed. Against this backdrop, one of the aims of this study is to investigate the issues that arise when Far East students from such environments study in a Western environment such as the UK.

Multicultural education literature often avoids the role of the subject discipline in the understanding of multicultural learning. Since disciplines can also be viewed as cultures (Becher, 1993), the understanding of multicultural education should also take account of the subject matter being taught. In the case of business education for example, it is commonly acknowledged that the practice of business worldwide is by no means homogeneous. The internet site www.worldbiz.com provides reports on business practices, customs and protocol, cross-cultural communication, negotiating, and etiquette when doing business in more than 120 countries. Academic literature has also acknowledged that, particularly in Asia, there are stark differences in the way business is being structured or carried out (e.g. Yau et. al., 2000). The Western view of business is basically selfish, opportunistic and instrumental, conforming to the philosophy of the market economy. In Milton Friedman's widely quoted words, "The social responsibility of business is to increase its profits" (Friedman, 1970). Good business is still perceived in the West to be hard-headed, aggressive and a 'lean and mean profit machine' through instructions such as 'The Lean Six-Stigma', a popular business methodology aimed at giving companies a competitive edge in a global marketplace (Sterman, 2005). Despite the rise of 'soft capitalism' i.e. "the rhetoric of new cultures of work and organisations, claiming self-motivation, self actualisation and emotions of belonging and sharing as the motivation for enhancing productivity and commitment to the organisation" (Heikkinen, 2004, p. 492; cf. Heelas, 2002), the firm's historical role in economic theory is price-guided (rather than management-guided) and serves the market for the benefit of shareholders. There is very little room for negotiation within such a philosophy for 'softer' issues. Yet, soft issues exist, for it is difficult to imagine that the function of an individual within a modern organization is fully and homogeneously logical, rational, self interested and instrumental. In fact, a scathing critique by Ghoshal (2005) suggests that business schools have condoned pessimistic assumptions of the human person within the firm, denying the ethical and moral responsibilities in business theories, and are in part responsible for corporate failures such as Enron's.

In contrast, Eastern business styles and organization are formed through the understanding of human interactions. Long before the current structure of economic societies and the organization of businesses, trade in Asia (as also in Europe) was already flourishing. Trade routes between China and the rest of Asia were the conduits for immigration, commerce, political maneuvering and cultural understanding, and the period between the mid-fifteenth to the mid-seventeenth century has been called the 'age of commerce' in Southeast Asia (Reid, 1988). Despite its long history, the knowledge of how and why commerce was so successful as it was is largely tacit, and East Asians have never explicitly understood, or documented, how they have made it work. To this day, many East Asian companies are still loosely structured, with very little sense of accountability, and with strong kinship biases. For example, Korean chaebols (conglomerates) that are responsible for the country's industrialization and increased standard of living over the last 40 years started as family businesses and are still family managed to this day. A study conducted in 1978 found that of 2,797 executives of large Korean enterprises, some twelve percent were directly related to the founders by blood or marriage (Kim and Kim, 1989) and another study found that thirty one percent of top executives were family members, forty 
percent recruited from outside and twenty nine percent promoted from within the firm (Lee and Yoo, 1987). One could argue that the rise of soft capitalism such as that described above in the West is born out of the need to generate trust, which is hard to come by in a pure capitalistic society (Thrift, 1998). Eastern communities rely on nepotism and kinship to generate that trust, as well as to reap the benefits of such trust - albeit in a manner that is less acceptable to modern Western sensibilities.

The Chinese are also generally considered to be a communal society whose lives tend to revolve around relationships (Nisbett, 2003). Simmons and Munch (1996) emphasize that "almost no other culture gives such high importance to maintaining interpersonal relationships ... They socialize while eating and drinking, but a major goal of this socialization is relationship-building". Nisbett (2003) also states that the Chinese tend to detect relationships more readily from events than Westerners and the achievement of harmony in relationships is the chief goal of Chinese social life. The building of relationships is the lifeblood of the Chinese community, with roots extending into politics, business and society (Luo, 1997).

In the eyes of today's Western world, many East Asian organizations are opaque and the legal systems in such economies immature (In praise of rules, 2001). Asia's embrace of today's Western-style capitalism is therefore seen as another pragmatic step towards better trade relations with the rest of the world, and an opportunity to learn the Western rules, through which investment and capital can then flow freely. Paradoxically, while Western business research is trying to learn the 'softer' skills of business, East Asian businesses are learning to be leaner and meaner. Or are they? While East Asian economies are learning the formal, transparent and explicit rules of business organization, such rules rest on a foundation of social, cultural and ethical habits that are too often taken for granted. Hence, while Ghoshal (2005) may charge that current business education propagates "ideologically inspired amoral theories" (p. 76) that free students from moral responsibilities, such responsibilities may already be embedded within the Asian social and cultural habit.

The above suggests that students who study business in the UK may, on one hand, have difficulties in learning due to cultural differences, and on the other, learn business in the Western context only to return to an environment that they are ill-equipped to manage. Western business education is amoral, and it avoids contextualizing its knowledge as far as possible, so that the knowledge can be imparted to multiple persons and applicable in various contexts. However, curriculum development in business education often implicitly assumes that the business context is within a Western-style domain, with its corresponding legal and socio-economic framework. With management theories and techniques originally developed in the West, this means that business educators need to be aware of a possibility of 'pedagogical imperialism' in their efforts to educate the Far East student. On the other hand, Westernstyle business organization is what the majority of today's business world subscribes to, and the appeal of Western education is in part because of this, as well as the belief that Western-style organization of business is fairer, given its rules of corporate governance, transparency and social responsibilities. Even businesses in Asia, despite the Eastern style, are changing, as testified by the recent incident of Hyundai where the Chairman's effort to ensure the succession of his son to chairmanship of the company has created a furore (Hyundai apologises, 2006). Yet tensions between Eastern and Western styles exist, and researchers have acknowledged that, particularly in China, local political, philosophical and cultural characteristics may result in different ways of organizing economic activity (Boisot and Child, 1996).

With globalization as an economic, cultural, and social homogenizing force (Crawford, 2000), there is a necessity to investigate the value of business education in the Western context to Far East students. This study therefore aims to gain insights into the following questions:

- What are the manifestations of culture that result in teaching/learning difficulties for Far East students in the UK?

- How do Far East students perceive the value of a Western based business education? 


\section{Researcher Position}

It is often acknowledged that the research process includes the position of the researcher (Sikes and Goodson, 2003). Hence, it is important to locate my position with respect to the research I am conducting so that the reader may understand the study from the perspective of my background, with the potential insights and biases that it brings.

As a female Malaysian Chinese, I was educated in Malaysia but completed my first degree in Singapore, in Physics. Being part of an entrepreneurial Chinese family, I started my working life in the family business environment immediately after graduation, and spent eleven years in senior management of large companies based in Malaysia. I decided then to embark on my doctoral studies in Marketing as I believed that there would be value in my business experience that could be brought into research and teaching. I found that I enjoyed research and the spirit of enquiry, and moved into a lectureship position in a business school in the UK.

I soon found out that, unlike many UK academics of Far East descent who have studied entirely in the UK, I came into the country very much wearing 'Far East lenses' (cf. Brookfield, 1995), without much acculturation. This, I felt, helped me to empathise with Far East students. Yet, after 3 years in the UK and being immersed in contemporary academic practice, the 'Western lens' has also been somewhat acquired. Having come to the UK and into academia late in life has helped keep the lenses separate and allowed me to see the strengths and weaknesses of both cultures in terms of the teaching and learning experiences. My aim in this study is to improve the school's understanding of students' learning experiences as well as to employ my cultural background, business experience and academic sensitivity to study a phenomenon that clearly embodies all three dimensions.

\section{Methodology}

Data was collected through notes taken on critical incidents (Tripp, 1993), in-depth student interviews and a focus group interview. Observations were obtained through interaction and conversations with postgraduate students from Taiwan (3 students), China (2 students), Thailand (3 students) and Singapore (1 student), in a business school of a UK university, where some $60 \%$ of the student population are from the Far East. The conversations and interactions were many, since I was directly responsible for postgraduate students at the school, as part of my administrative duties. As such, I had first hand encounters with problems, issues and discussions pertaining to the postgraduate student community within the school. Other observational and anecdotal data was also collected from minutes of meetings, comments from module instructors teaching postgraduate Far East students and discussions with colleagues on teaching issues.

Soliciting opinions and thoughts from Far East students through interviews was difficult. Two particular difficulties are noted. First, social desirability (i.e. the inclination to respond in a manner that is socially desirable, rather than expressing one's true feelings) has a particularly strong influence on Far East students. Hence, many conversations started with students reporting how they thought they should feel, rather than how they actually felt. Only after obtaining much data over time and gaining some measure of trust did the actual feelings slowly materialize. Secondly, some Far East students were keener to understand why I was asking the question than to give an honest answer. The belief was that there was a right answer to the question, and they wanted to be helpful. Thirdly, many Far East students were often reluctant to say anything negative about any situation: to get the data, questions had to be triangulated so that answers clearly showed any negative feelings without informants' explicitly saying so. Three categories of insights are presented below.

\section{Results}

\section{Thinking and Communication Strategies}

Observations from teaching Far East students both in the Far East and in the UK, as well as indepth student interviews, suggest that the degree of risk aversion, particularly an aversion to appearing 'wrong', is high amongst such students. As such, Eastern students are not generally participative in class 
discussion. However, being in the UK seems to give students the perception that their thoughts may be allowed a little more freedom. Some admit that they "dare to speak out" a little more in the UK than they would do otherwise. The multicultural environment seems to allow for less inhibition, much as anonymity in an online chat room makes the chatter less inhibited. Students also admitted that learning how to speak out helps them 'be distinctive'. One student claimed that "Employers will see a difference between you and other employees because it shows that you have a mind of your own". Thus, students find that those that speak out more are rewarded with a growing confidence, although they acknowledge that they would act differently if they were back in their own home country. The findings show that Far East students, ever the pragmatists, behave according to the environment.

Almost all students interviewed claimed to appreciate learning the ability to think critically, defined by Angelo (1995) as "intentional application of rational, higher order thinking skills, such as analysis, synthesis, problem recognition and problem solving, inference, and evaluation" (p. 6). This skill clearly fascinated Far East students; yet many see it as a distinctively "Western logic". Students remarked that when they go back to Asia, they have to be careful with this way of thinking as it may not be acceptable to others. When I asked if learning such a way of thinking is advantageous, they mostly agreed, but one student commented that "of what use if to put it to practice might land them more into trouble"? The findings also show that Far East students perceive that lessons in critical thinking serve them in two ways: firstly to learn how to think critically themselves (although they may not wish to practice it in an Asian environment) and secondly "at least, we know how the westerners think, so if we work in a Western company, we know the Western logic". One student who has worked in a Western company in the Far East added cynically that even so, Westerners working in the Far East tend to follow the Eastern model - they seem to accept critical thinking from Western employees but not from Asians.

\section{Dissonance}

There is considerable dissonance detected in these students regarding learning business in the UK, although they cope with the dissonance in many different ways. Since the Western model of business is amoral, many business schools introduce subjects such as ethics and corporate social responsibility so as to bring some degree of social conscience into business, particularly after lessons learnt from major corporate scandals such as Enron and Worldcom. Yet, Far East students often avoid taking such modules. When asked why, three reasons are revealed.

First, many Far East students could not identify with the topics. Students think of themselves not as the company, but merely employees performing their tasks. "It's not about what I think is ethical", says one student, "but what I have to do in a company. It's my job, I just have to do it, ethical or not". When asked about the ethical decisions they might make if they are empowered to do so on behalf of the company, a typical position was that "the company has to make money: that is more important. If the company is already making money, we can probably afford to be more responsible".

Second, there is clearly dissonance faced by the students in the study of ethics and social responsibility and what they see as "the real world of business in Asia". Interestingly, students manage the dissonance by viewing such studies as "Western logic". Asian societies are different, they charge, because we are young and we have different priorities. As one student claimed, "the competition is keen, the pace is very fast, and we have to be more money minded. To survive, to compete, we need to set aside ethics and environment and all these things". Clearly some students accept the amorality of the Western business model, and reject the introduction of "social conscience" subjects into the curriculum.

Finally, dissonance has led to some students arguing that "what the Westerners call unethical may not be what we call unethical". Yet students acknowledge that 'we have to learn what they consider to be ethical, you see, so that if we need to change to suit them, we know how we should change i.e. we know their rules'. Clearly, Far East business students see a dividing line of 'them' and 'us' in the study of business, in part to reduce the level of dissonance.

Students see that a lot of what is taught is 'Western' but they see the value of what is taught even if they think there is limited applicability - just to know what business is like in the West. They adopt those principles that they think are workable and reject others. When asked if they think instructors are 
ethnocentric in their instruction and content, students seem to think that it is necessary for instructors to be ethnocentric, so that they can see how instructors think, as they (the instructors) represent the business thought of the West. When asked how they would like it if a Western instructor taught the Eastern style of doing business (if such a style exists) one student said, "unless you are doing research in Asia, or have worked there a long time, or are an Asian yourself, it's better to teach the Western way and let us decide what could be useful in Asia".

\section{Epistemology}

Learning by rote has made Asians essentially positivistic in their view of the world. There is a right and a wrong way of doing things and an 'objective' way is necessary to ensure harmony, so that there can be a meeting of minds. Hence, everyone is expected to conform to what's 'right'. Knowledge is often seen as received information, and memorization as valuable. This has serious implications when Asian students attempt to deliver a dissertation. Often, dissertations by Far East students are a regurgitation of facts; at the extreme, students blatantly plagiarize. Part of the reason is because they often mistakenly assume that the value of a dissertation is in how much information can be delivered into the thesis. One confused student asked "if I don't report the facts, what is the value of my work?" Many don't understand why plagiarism is a problem. One student says "I cite the author and the source in my work; why can't I use his sentences? He says it better!" Another student says, "if I don't write down all that I've read, how does the examiner know that l've read them? He must know that I have studied, that I have made the effort, right?" Even in examinations, students often misunderstand: in open book exams, students become confused. "How do I show you what I have learnt, if it's an open book examination?"

\section{Signalling}

Students claim that UK education sends the 'right' signal to employers. One student says "If I am educated in the UK, a Western company will know that I know the Western concepts". Another added, 'If I have a UK degree, they will know that my English is good'. The latter, ironically, was said by a student whose English was so poor that she had to say it in her native language and her words translated by her classmate. When asked about the learning acquired, the student shrugs. "Not much. But have to make sure I pass all the exams to get the degree". Clearly, many students value the certification more than the learning. Employability is always a big issue with students, but strategies (including the type of CV presented) differ if applying to a UK company as opposed to one in Asia: "UK companies focus on skills; Asian companies focus on your qualifications so you have to modify it accordingly".

\section{Discussion of Findings}

My data suggests that cultural habits lead Eastern students to think that there is always a 'right' answer as opposed to a 'good' answer. Compounding the issue is that students are not willing to risk thinking creatively. This is consistent with Gass's (1998) observations of Far East students when he comments that "[students] understand that to think creatively is to risk error, and they'd rather not."

Cultural habits also lead students into being role-driven. Hence, much behavior is justified according to where they are and what they are tasked to do. Although some may argue that this is inconsistent and contradictory, it may not be so when one considers the philosophical underpinnings of the Eastern culture - that one's identity is often collective and must be contextual. When an Easterner's identity is linked to the environment, a 'business mode' person is to do what he is required to do in business. This, in their perception, is not relevant to what or who the person 'truly' is (and the notion that there exists such a 'true' person is also debatable in Eastern terms). Past research has shown that it is not a contradiction for a Japanese man to be an aggressive manager in the office, and to be meek and submissive to a wife at home (Fukuyama, 1996). The role-in-context is the dominant driver of behavior, and pragmatically this role determines what a person should be, within whatever environment $\mathrm{s} / \mathrm{he}$ is in.

The findings in this study and also from others (e.g. Cheng, 1990; Wang et. al., 2005) show that harmony, above all else, is to be preserved, and the one that disrupts it is not to be given credit, even if what he is saying is right. To say that Easterners care more about harmony than being correct misses the point: the point is to be right and to communicate it effectively, fitting in with opposing viewpoints and 
therefore without a need to disrupt harmony. That is perceived to be the ultimate skill. Students consider that Westerners don't seem to make that effort and that in the West it is only important to be right.

The findings also suggest that much of the education in the Far East is learning by rote. Memorization, and not critical thinking, is therefore the key to academic success. The consequence of such thinking has contributed to Far East students' lack of critical thinking skills which are often necessary in a Western environment. Part of the reason is because Confucian culture necessitates the treatment of teachers' words as the gospel truth. Students have not been conditioned to think critically, not merely because they do not know how, but because students may fear that voicing evaluative thoughts that debate and discuss the issues taught may seem like criticism and may be construed as an insult to their teacher. Set against this background, entering into the UK environment requires considerable 're-conditioning' of the mind.

Clearly, learning critical thinking is a skill highly valued by Far East students, but students felt that they could choose to think in one way or another, depending on the circumstances. There is also dissonance faced in terms of what students value about Western-based business education and what instructors think they should value (e.g. ethics and social responsibility). However, a counter-intuitive finding shows an inherent link between ethnocentricity and the value of business education. Is it wrong to be ethnocentric when business, as a subject that is developed and organized in a Western environment is valued precisely because of that? While multicultural education aims to be free of inherited biases (Parekh, 1986), would this not conflict with the value of business education which, as a subject, is desired to be specific to Western culture? The findings suggest that students need to be given the right to choose - even if they choose to subscribe to imperialistic notions - as only they themselves can evaluate the losses and rewards that come with their choices. Ironically, it also means that educators who are careful not to indulge in cultural imperialism fall prey to exactly that if they deprive the students of that choice. Far East students, with an intrinsic nature of being drawn to harmony, are often willing to acculturate for perceived rewards (e.g. collective good) that they believe could be obtained from acculturation.

\section{Recommendation}

The results also indicate that a lack of understanding of students' cultures may result in instructors misinterpreting students' intellectual abilities. Western instructors often assume that their notion of the value of knowledge and how it can be conveyed and learnt has little to do with culture. However, researchers (e.g. Kimball, 1978) as well as the findings here suggest that culture influences all dimensions of learning. While instructors may think that students show 'poor analytical skills', or are 'slow in learning', it is important to understand that the lack of such skills may be a legacy from a different education culture and the acquisition of such skills may lie in improving students' learning abilities by developing their meta-cognition, i.e. the "knowledge and awareness of one's own cognitive processes (Flavell 1976) and the ability to monitor, regulate and evaluate one's thinking" (Brown 1978),. In other words, students could improve markedly once they are aware of the skills required in a Western context.

Furthermore, when students do poorly in certain subjects, there may be a tendency to blame poor English, particularly when many Far East students do not speak English as a first language. While the mastery of English language remains the most important skill to be acquired to facilitate learning in a Western environment, there is also a need to assist students in understanding the epistemological foundations of Western-based education. Where the design of a course requires students to think in a certain way (e.g. dissertations), students should be made aware of the nature, generation and value of such knowledge, rather than simply be given the rules of behavior. Of course, there will always be a minority of students that intentionally plagiarize to avoid doing the work, but it is important for institutions to put in place a system to identify these, and to offer assistance to those who require it.

The study also finds the need for a starting point to bridge the gap between Far East students and the applicability of what is taught in business. Dissonance occurs often because students see conflicts and are not given ways to reconcile them - hence they reduce the dissonance in their own way, resulting in the possibility of misinterpreting what is taught. Thus, in line with lessons learnt from multicultural education, instructors could "start teaching where students are" and "expand the social, cultural, and 
intellectual horizons of students" (Gay, 1994: Teaching and Learning T9) to reduce dissonance. Education literature indicates that learning is more effective when new ideas are related to previous knowledge and are taught initially in ways familiar to students (Neisser, 1986). Of course, this means that there is a need to increase the cultural competency and literacy of instructors.

Finally, UK universities are obviously valued for quality in education. Yet the results presented here show a worrying trend whereby students value only the certification, and not the learning. Many UK universities are 'old brands', with promises of a pedigree education (though what that means varies with different people). Universities have to understand what that promise involves, and deliver accordingly. The danger is for students to attend UK universities to get a degree simply because the certification promises better job prospects, regardless of the learning experienced. In the extreme, the learning experience becomes a cost, rather than a benefit, to the student particularly when gaps exist that make students perceive the learning to be less relevant towards their employability ( $\mathrm{Ng}$ and Forbes, 2006). Instructors therefore need to increase the relevance of their courses as well as develop their own cultural competency and literacy, because educational experiences should be perceived as personally meaningful to students. Where a course requires the instructor to make assumptions (and almost all business courses do to some extent), such as applicability towards the Eastern context, it is therefore necessary for instructors to be aware of such assumptions and make them explicit where necessary. Students can then consider whether the assumptions hold in their own cultures, rather than make their own assessments of what can or cannot work. Much of what is taught in business schools is actually relevant across cultures. However, when students do not think so, they lose interest and learning becomes a chore.

\section{Conclusion}

In this age of rapid globalization, education has a big role to play, both in terms of being an economic activity and of changing the classroom's multicultural dynamics. This study shows that when Far East students go abroad to study, almost everything is up for negotiation: culture, ethnicity, philosophy, and values. Students evaluate what they like or dislike, and re-define their own identities. They learn how the game is played, and in some cases, willingly acculturate themselves.

The study presented here examines the challenges of learning (and hence teaching) business across cultures, both in terms of difficulties encountered in teaching students of different cultural norms and in terms of what such students value in a Western business education when the application of it is in an Eastern context. These challenges would manifest themselves in all four modes of supply in higher education services according to the General Agreement on Trade in Services (GATS): cross-border supply (e.g. distance learning or e-education), consumption abroad (students studying outside their own country), commercial presence (e.g. branch campus, franchises etc.) and Presence of Natural Persons (mobile instructors) (Knight, 2002). In all four modes, students and instructors would typically come from different cultures. The study raises the question of what instructors should do to develop cultural competency and literacy so that a UK business degree would continue to be valued. Finally, it is not the aim of this chapter to claim that the issues here are generalizable to all Far East students. Indeed, with globalization, immigration and increasing labour mobility, it would be difficult to discern the way culture, education and lifestyles combine in any one person. This study aims to demonstrate some learning and teaching issues that may arise as students from the Far East go abroad for their studies. Further research could run quantitative tests to examine the prevalence of such challenges, as well as how other teaching techniques such as practice-informed teaching could help increase relevance and reduce the learning/teaching gap.

\section{Discussion/Reflection Questions}

1. Can we be so sure that the prevailing method of education and thinking in the West is the best way, just because so many Far East students subscribe to it?

2. With all the good intentions of not being ethnocentric, are we depriving students from learning the perspectives seen from our own (Western) culture? 
3. How do we construct curriculum so that students are aware of subjects being culturally laden even though they are willing to accept its wisdom and teachings?

4. How do we assist students in negotiating the applicability of Western based education in their home country?

5. In what way is your subject area historically and culturally constructed?

\section{Resources}

Ghoshal, S. (2005), "Bad Management Theories are Destroying Good Management Practices," Academy of Management Learning and Education, Vol,. 4, No.1, pp75-91

This paper is useful to understand the fundamental assumptions of management theories often taught in business schools today. Ghoshal attacks such assumptions as they allow business school academics to develop scientific and empirical model and to engage in a pretence of knowledge where there was none.

Hamilton, G.G. and Biggart, N.W. (1988), Market, Culture, and Authority: A Comparative Analysis of Management and Organization in the Far East. American Journal of Sociology 94: pp52-9

In trying to understand decision making in organizations, there are three approaches. The market approach study the conditions in firms operate in a market economy. The second approach looks at the role of culture and how economic behavior is shaped by it and the third approach is the political economy approach, focusing on decision making from the perspective of power and authority. This paper looks at the three approaches as they relate to the developed economies of Japan, Taiwan, and Korea.

Watkins, D. and, Biggs, J. (Eds.). (1996). The Chinese Learner: Cultural, Psychological and Contextual Influences. Hong Kong: Central Printing.

This book researchers on the paradoxical question of how Chinese learners can be successful academically when their teaching and learning seems to be learning by rote and memorization. It shows that cross-cultural differences exist in the processes of teaching and learning and explains the relationship between memorizing and understanding and the nature of motivation.

Nisbett, R. (2003), The Geography of Thought: How Asians and Westerners Think Differently...and Why, Free Press

This book proposes that Asians and Westerners "have maintained very different systems of thought for thousands of years" and that East Asians are more holistic in their perceptions (i.e. perceiving a scene as a whole) whilst westerners have a more "tunnel-vision perceptual style" that focuses on selecting objects from scenes and remembering them.

\section{References}

Ameny-Dixon, G.M. (2004). Why multicultural education is more important in higher education now than ever: A global perspective. International Journal of Scholarly Academic Intellectual Diversity, Volume 8, Number 1 accessed online at http://www.nationalforum.com/dixon.htm

Angelo, T. A. (1995). Beginning the Dialogue Thoughts on Promoting Critical Thinking: Classroom Assessment for Critical Thinking. Teaching of Psychology. Vol. 22, No.1, pp6-7

Becher, T. (1993). Academic Tribes and Territories: Intellectual Enquiry and the Culture of Disciplines. Buckingham: The Society for Research into Education and Open University Press.

Bennett C.I (2003) Comprehensive Multiciltural Education: Theory and Practice. Boston: Pearson Education Inc.

Boisot, M and J. Child (1996). From Fiefs to Clans and Network Capitalism: Explaining China's Emerging Economic Order. Administrative Science Quarterly, Vol. 41 
Brookfield, S. D. (1995). Becoming a Critically Reflective Teacher. John Wiley and Sons

Brown, A. L. 1978. Knowing when and how to remember: A problem of metacognition. In Advances in instructional psychology (Vol. 1), edited by R. Glaser, 77-165. Hillsdale, NJ: Erlbaum.

Cheng, S.K. (1990). Understanding the culture and behaviour of East Asians--a Confucian perspective. Aust N Z J Psychiatry. Vol. 24, No. 4, pp510-515

Crawford, D (2000). Chinese Capitalism: Cultures, the Southeast Asian Region and Economic Globalisation. Third World Quarterly, Vol. 21, No. 1, pp 69-86

Daniel, J (2004). Education Across Borders: What is Appropriate?". The $1^{\text {st }}$ UK International Education Conference, Going Global: The Internationalization of Education. Edinburgh, UK, 9 Dec.

De Bono, E (1996). Textbook of Wisdom, Penguin and Putnam

Flavell, J. H. 1976. Metacognitive aspects of problem solving. In The nature of intelligence, edited by L. B. Resnick: 231-236. Hillsdale, NJ: Erlbaum.

Friedman, M. (1970). The Social Responsibility of Business Is to Increase Its Profits. New York Times Magazine, 1 September 1970. Reprinted in Beauchamp, T.L. and Bowie, N.B. (eds., 1993). Ethical Theory and Business. Englewood Cliffs, N.J.: Prentice-Hall.

Fukuyama, F. (1996) Trust: The Social Virtues and Creation of Prosperity London: Penguin

Gass, L (1998). Teaching for creativity in science: An example," CDT Link, Centre for Development of Teaching and Learning, National University of Singapore, available at <http://www.cdtl.nus.edu.sg/link/jul1998/practice1.htm> accessed 19 Apr 2006.

Gay, G (1994). A synthesis of scholarship in multicultural education. Urban Education Monograph Series, NCREL Urban Education Program. Retrieved 12 June 2006 from <http://www.ncrel.org/sdrs/areas/issues/educatrs/leadrshp/le0gay.htm>.

Ghoshal, S (2005). Bad Management Theories are Destroying Good Management Practices. Academy of Management Learning and Education, Vol,. 4, No.1, pp75-91

Gollnick, D. M. and P.C. Chinn (2002). Multicultural Education in a Pluralistic Society, $6^{\text {th }}$ edition, Upper Saddle River, NJ: Pearson Education Inc.

Green, M.F. (1989). Minorities on Campus: A handbook for Enhancing Diversity, Washington DC: American Council on Education

Heelas, P. (2002). Work Ethics, Soft Capitalism and the 'Turn to Life', in P. du Gay \& M. Pryke (Eds) Cultural Economy, pp. 78-96. London: Sage.

Heikkinen, A (2004). Evaluation in the Transnational 'Management by Projects' Policies. European Educational Research Journal, Vol 3, No. 2, pp486-500

Higher Education Statistics Agency (2006). 6.1 Per Cent Increase in Overseas Students for 2004/05: Business And Admin Retains Most Popular Subject Status. Press Release, PR97, 13 March. Retrieved 15 August 2006 from <http://www.hesa.ac.uk/press/pr97/pr97.htm

Hwang, K. (1987). Face and Favour: the Chinese Power Game. American Journal of Sociology, vol. 92, pp.944-974

Hyundai apologises (2006). Hyundai apologises amid scandal. BBC News online, 19 Apr 2006, http://news.bbc.co.uk/2/hi/business/4921350.stm accessed 25 Apr 2006.

In Praise of Rules 2001. In Praise of Rules: A Survey of Asian Economies. The Economist, 5 Apr, http://www.economist.com/surveys/displaystory.cfm?story_id=E1_VVJPRJ, accessed 15 Aug 2006

Kim, K. C. and S. Kim (1989). Kinship Group and Patrimonial Executives in a Developing Nation: A Case of Korea. Journal of Developing Areas, Vol. 24, p. 27 - 46 
Kimball, S.T. (1978). The transmission of culture. In J.I. Roberts \& S.K. Akinsanya (Eds.), Schooling in the cultural context: Anthropological studies of education (pp. 257-271). New York: David McKay Company.

Knight, J. (2002). Trade in Higher Education Services," A Report from the Observatory on Borderless Higher Education, Global Forum on International Quality Assurance, Accreditation and Recognition of Qualifications in Higher Education, UNESCO, <http://www.unesco.org/education/studyingabroad/highlights/global_forum/gats_he/jk_trade_he_gats_im plications.pdf> accessed 2 Apr 2006

Lau, A. and B. Roffey (2002). Management Education and Development in China: A Research Note. Labour and Management Development Journal, Vol. 2, No. 10, pp1-18

Lee, S. M. and S. Yoo (1987), "The K-Type Management: A Driving Force of Korean Prosperity," Management International Review, Vol. 27, P. 68-77

Luo, Y. (1997). Guanxi: Principles, Philosophies and Implications. Human Systems Management, vol. 16 , no. 1 , pp. $43-52$

No. 4, pp99

McGugan, I. (1995). Canada's Hottest Export - Business Professors. Canadian Business, Vol. 68,

McNaught, K. (1988), A Penguin History of Canada, Penguin Books.

McNergney, R.F. and J.M. Herbert (2001), Foundations of Education: The Challenge of Professional Practice, Boston: Alyn and Bacon

Neisser, U. (Ed.). (1986). The school achievement of minority children: New perspectives. Hillsdale, NY: Laurence Erlbaum.

Ng, I. C. L., (2006). Photoessays in the Teaching of Marketing. Journal of Marketing Education, Vol. 28 No. 3, December, pp1-17

$\mathrm{Ng}$, I. C. L. and J. Forbes (2006). Education as Service: The Understanding of University Experience through the Service Logic. Proceedings of the 9th International Research Seminar in Service Management, 30 May - 2 June 2006, La Londe, France

Nisbett, R. (2003). The Geography of Thought: How Asians and Westerners Think Differently... and Why. Free Press, New York

Ortner, S. (2003), "East Brain, West Brain," The New York Times, April 20, http://query.nytimes.com/gst/fullpage.html?res=9804E5DA163BF933A15757C0A9659C8B63 accessed 15 Aug 2006.

Parekh, B. (1986). The concept of multicultural education. In S. Modgil, G.K. Verma, K. Mallick, \& C. Modgil (Eds.), Multicultural Education: The interminable debate (pp. 19-31). Philadelphia: Falmer.

Reid, A. (1988). Southeast Asia in the Age of Commerce, 1450-1680, Vol.1, Yale University Press, New Haven.

Sterman, P. (2005). Lean and Mean Profit Machines: UC Irvine Extension teaches corporations how to compete, OC Metro, 21 July

Sikes, P. and I. Goodson (2003). Living Research: Thoughts on Educational Research as Moral Practice in P. Sikes, J. Nixon and W. Carr (eds), The Moral Foundations of Educational Research: Knowledge, Inquiry and Values, Maidenhead: Open University Press

Simmons, L.C. and J.M. Munch (1996). Is Relationship Marketing Culturally Bound: a Look at Guanxi in China. Advances in Consumer Research, vol. 23, pp. 92-96.

Stuart-Fox, M. (2003). Short History of China and Southeast Asia: Tribute, Trade and Influence, Allen and Unwin 
Thrift N, (1998). The rise of soft capitalism. in An Unruly World? Globalization, Governance and Geography Eds A Herod, G O Tuathail, S M Roberts, Routledge, London, pp 25 - 71 Routledge

Tripp, D. (1993). Critical Incidents in Teaching: Developing Professional Judgement, New York,

Trotman, C. J. (ed.) (2002). Multiculturalism: Roots and Realities, Indiana University Press

Tsang, E.W.K. (1998). Can Guanxi be a Source of Sustained Competitive Advantage for Doing Business in China?. Academy of Management Executive, vol. 12, no. 3, pp. 64-73

Turner, T. (1994). Anthropology and multiculturalism: What is Anthropology that Multiculturalists should be mindful of it? in D.T. Goldberg (Ed.) Multiculturalism: A Critical Reader (pp406-425), Oxford: Blackwell

University Enrolment (2005). The Daily, Tuesday, October 11, http://www.statcan.ca/Daily/English/051011/d051011b.htm accessed 15 Aug 2006

Wang, J., Wang, G.G., Ruona, W.A. and Rojewski, J.W. (2005). Confucian values and the implications for international HRD. Human Resource Development International, Volume 8, Number 3, pp311-326

Yau, O.H.M., P. R. McFetridge, R. P.M. Chow, J. S.Y. Lee, Leo Y., M. Sin and A.C.B. Tse, (2000). Is Relationship Marketing for Everyone?. European Journal of Marketing, Vol. 34, No. 9/10, pp1111-1127

\section{Author}

Dr. Irene $\mathrm{C} \mathrm{L} \mathrm{Ng}$ is with the School of Business and Economics, University of Exeter (U.K.). Contact Information: School of Business and Economics, University of Exeter, Streatham Court, Rennes Drive, Exeter EX4 4PU, United Kingdom Tel: +44 (0) 1392 263250, Fax: +44 (0) 1392 263242, Email: $<$ Irene.Ng@exeter.ac.uk>.

\section{Biographical Information}

Irene $\mathrm{Ng}$ is a Senior Lecturer in Marketing, the Director for the Centre for Service Research and the Head of Postgraduate Studies at the School of Business and Economics, University of Exeter (U.K.). Irene was the CEO of SA Tours group (Malaysia), CEO/President of Empress Cruise Lines (Malaysia) from 1988-2003 and is currently the Group Vice Chairman of the SA Tourism group with regional offices in Singapore, Malaysia, and China. Irene obtained her Ph.D. from the National University of Singapore and has published in various international business journals. Her interest in contemporary academic practice and education has also seen a recent publication in the Journal of Marketing Education. She has taught in Executive and MBA programs worldwide and is also a marketing advisor to several international firms in Singapore, Malaysia, South Africa, Australia, and the U.K. She currently resides in the UK but spends half the year in Asia.

${ }^{1}$ By the term 'Far East', I mean students who come from countries with roots in Confucianism such as Korea, Japan, China, Taiwan, Hong Kong, Singapore and the overseas Chinese in Thailand and Malaysia. Throughout the chapter, the terms 'Far East' and 'Eastern' are used interchangeably.

${ }^{2}$ We define 'Western' thinking as those originating from the Aristotelian philosophies i.e. European and American cultures

${ }^{3}$ Nisbett, Richard (2003), The Geography of Thought: How Asians and Westerners Think Differently... and Why, The Free Press: pp44-5

${ }^{4}$ Ibid. p171 